\title{
Incidentally detected Gerbode defect in a patient of type 2 diabetes mellitus
}

\author{
Monu Rani, ${ }^{1}$ Rajesh Nandal, ${ }^{2}$ Mohini Asija, ${ }_{1}^{1}$ Rajesh Rajput ${ }^{1}$
}

'Department of Endocrinology \& Medicine, Pt BD Sharma Postgraduate Institute of Medical Sciences, Rohtak, India ${ }^{2}$ Department of Cardiology, Pt BD Sharma Postgraduate Institute of Medical Sciences, Rohtak, India

Correspondence to Dr Rajesh Rajput; drrajeshrajput@outlook.com

Accepted 1 July 2020
Check for updates

(c) BMJ Publishing Group Limited 2020. No commercial re-use. See rights and permissions. Published by BMJ.

To cite: Rani M, Nandal R, Asija M, et al. BMJ Case Rep 2020;13:e235940. doi:10.1136/bcr-2020235940

\section{DESCRIPTION}

A 44-year-old woman, known case of type 2 diabetes mellitus with poor glycaemic control (glycated haemoglobin 10.8\%), was hospitalised for continuous glucose monitoring (CGM). On enquiring retrospectively during her hospital stay, she also reported a history of effort intolerance, palpitation and exertional dyspnoea (New York Heart Association class II) for 5 years, which she neglected. There were no reports of angina, orthopnoea, paroxysmal nocturnal dyspnoea and pedal swelling. Also there was no history of valvular heart disease, systemic hypertension or blood transfusions. Considering and taking note of all these symptoms, in addition to CGM, patient was thoroughly examined and investigated.

The cardiovascular examination shows normal precordium with apical impulse in left sixth intercostal space (ICS), no palpable thrill, resonant second ICS and no parasternal heave. On auscultation grade III pansystolic murmur was heard over the entire precordium, with maximum intensity along lower left sternal border, without any radiation to axilla. S1 and S2 could not be appreciated in mitral and tricuspid area due to murmur. S2 was heard normally over pulmonary area, with no evidence of loud P2. On dynamic auscultation, murmur intensity increased with inspiration, squatting from standing position and handgrip manoeuvre, while reduced after standing and valsalva manoeuvre. There was no evidence of cyanosis, clubbing and tender hepatomegaly. The jugular venous pressure was $7 \mathrm{~cm} \mathrm{H} \mathrm{H}_{2} \mathrm{O}$.

The ECG shows sinus rhythm with no evidence of left/right ventricular hypertrophy. Chest roentgenogram did not show any evidence of cardiomegaly or dilated pulmonary artery. The transthoracic echocardiography (TTE) revealed normal left ventricular ejection fraction, mildly dilated right atrium (RA) and $\sim 6-7 \mathrm{~mm}$-sized ventricular septal defect (VSD) connecting left ventricle (LV) to RA with left-to-right shunt through tricuspid valve (TV), suggestive of Gerbode defect. Transoesophageal echocardiography (TOE) confirmed the findings of TTE (figures 1 and 2) showing turbulence flow through the defect (online supplementary videos 1 and 2), with a pressure gradient of $\sim 110-120 \mathrm{~mm}$ $\mathrm{Hg}$. She was planned for surgical repair of the defect.

Gerbode defect is a rare type of VSD, with direct communication between LV and RA, accounting for $0.08 \%$ of intracardiac shunts and $<1 \%$ of all congenital cardiac defects. ${ }^{1-3}$ It was first described in $1838^{4}$ and named after

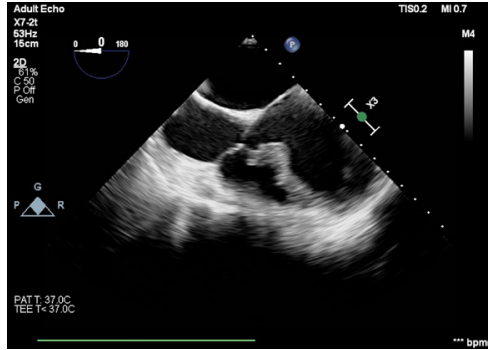

Figure 1 Transoesophageal echocardiography (TOE) midoesophageal (ME 0 degree)-four-chamber view showing communication between the left ventricle to the right atrium through the tricuspid valve.

Gerbode $e t a l^{5}$ successfully performed surgery on five patients with this defect in 1958. The supravalvular (direct shunt), infravalvular (indirect left-toright shunt with associated TR) and mixed are three major types of the defect. The clinical presentations include asymptomatic cases, chest pain, shortness of breath, lower extremity oedema, severe right and/or left heart failure with high mortality; based on size, volume and duration of the shunt. ${ }^{16}$ Most patients have a systolic murmur, heard over the entire precordium. ${ }^{17}$

TOE serves as the most sensitive modality for detecting LV-RA shunts. ${ }^{7}$ The infra-valvular defect shows unidirectional shunt flow across the TV; thereby differentiating it from Eisenmenger VSD with Tricuspid Regurgitation (TR) exhibiting bidirectional shunt flow. ${ }^{8}$ Gerbode defect typically shows a systolic left-to-right shunt that needs to be differentiated from ruptured sinus of valsalva aneurysms, which also shows shunting of blood during diastole due to diastolic gradient established between aorta and RA. ${ }^{8}$ The surgical management of the defect is done based on the severity

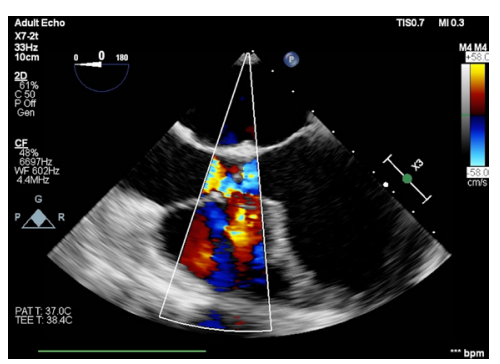

Figure 2 Transoesophageal echocardiography (TOE) midoesophageal (ME 0 degree)—four-chamber view with colour doppler showing turbulent flow from the left ventricle to the right atrium through the tricuspid valve. 


\section{Learning points}

- Gerbode defect is a rare cardiac anomaly and is a type of ventricular septal defect (VSD), with direct communication between left ventricle and right atrium.

- Patients with Gerbode mostly have a systolic murmur, heard over the entire precordium.

- The clinical presentation, physical examination and findings of echocardiography serve as the important aid to the differential diagnosis of infravalvular Gerbode defect from Eisenmenger VSD with tricuspid regurgitation.

of symptoms, clinical judgement and presence of comorbid conditions.

The detailed history considering all the symptoms that the patients present with and the physical examination carries utmost importance even in the era of advanced investigations and diagnostics. If carefully considered, they serve as valuable guide to use these advancements for timely diagnosis and planning intervention in patient care (as in our case), thereby halting disease progress and preventing complications.

Contributors RR conceived the idea of the case report. RR, RN and MA provided the scientific guidance for the workup of the case. MR has worked with the case investigations, acquisition and interpretation of the data. MR and RN have worked for drafting and reporting the manuscript.

Funding The authors have not declared a specific grant for this research from any funding agency in the public, commercial or not-for-profit sectors.

Competing interests None declared.

Patient consent for publication Obtained.

Provenance and peer review Not commissioned; externally peer reviewed.

\section{REFERENCES}

1 Taskesen T, Prouse AF, Goldberg SL, et al. Gerbode defect: another nail for the 3D transesophagel echo hammer? Int I Cardiovasc Imaging 2015;31:753-64.

2 Wasserman SM, Fann JI, Atwood JE, et al. Acquired left ventricular-right atrial communication: Gerbode-type defect. Echocardiography 2002;19:67-72.

3 Tidake A, Gangurde P, Mahajan A. Gerbode Defect-A rare defect of atrioventricular septum and tricuspid valve. J Clin Diagn Res 2015:9:0D06-8.

4 Thurnam J. On aneurisms of the heart with cases. Med Chir Trans 1838;21:187-265.

5 Gerbode F, Hultgren H, Melrose D, et al. Syndrome of left ventricular-right atrial shunt; successful surgical repair of defect in five cases, with observation of bradycardia on closure. Ann Surg 1958;148:433-46.

6 Sinisalo JP, Sreeram N, Jokinen E, et al. Acquired left ventricular-right atrium shunts. Eur J Cardiothorac Surg 2011;39:500-6.

7 Yuan S-M. A systematic review of acquired left ventricle to right atrium shunts (Gerbode defects). Hellenic J Cardiol 2015;56:357-72.

8 Silbiger JJ, Kamran M, Handwerker S, et al. The Gerbode defect: left ventricular to right atrial communication-anatomic, hemodynamic, and echocardiographic features. Echocardiography 2009;26:993-8.

Copyright 2020 BMJ Publishing Group. All rights reserved. For permission to reuse any of this content visit

https://www.bmj.com/company/products-services/rights-and-licensing/permissions/

BMJ Case Report Fellows may re-use this article for personal use and teaching without any further permission.

Become a Fellow of BMJ Case Reports today and you can:

- Submit as many cases as you like

- Enjoy fast sympathetic peer review and rapid publication of accepted articles

- Access all the published articles

Re-use any of the published material for personal use and teaching without further permission

\section{Customer Service}

If you have any further queries about your subscription, please contact our customer services team on +44 (0) 2071111105 or via email at support@bmj.com.

Visit casereports.bmj.com for more articles like this and to become a Fellow 